\title{
Bibliography
}

Adriaenssen, Leo, Staatsvormend geweld (PhD thesis, Tilburg University, 2007).

Aitsinger, Michael, De leone Belgico, eiusque topographica atque historica descriptione liber ... Rerumque in Belgio maxime gestarum, inde ab anno Christi MDLIX usque ad annum MDLXXXIII perpetua narratione continuatus (Cologne: Impensis Francisci Hogenbergii, 1583).

Anderson, Clare, et al. (eds), Mutiny and Maritime Radicalism in the Age of Revolution. A Global Survey (Cambridge: Cambridge University Press, 2013).

Anonymous, Belägerung der Statt Ostende. Iournal: Tagregister vnd eigentliche beschreibung aller gedenckwurdigsten Sachen [...] (s.l.: s.n., 1604).

Anonymous, Cort, ende warachtich verhael van de verraderye der stadt van Liere: gheschiedt door capiteyn Semple met syne Schotten, die aldaer in garnisoen ligghende, de selve hebben verraden, ende den vyanden ghelevert, int iaer 1582, op den tweeden dach Augusti (1582). Royal Library The Hague, Knuttel collection 616.

Anonymous, Dag-Verhael, gehouden binnen Leiden, in R.J. Fruin, J.E.H. Hooft van Iddekinge and W.J.C. Rammelman Elsevier (eds), De oude verhalen van het Beleg en Ontzet van Leiden bij gelegenheid van het derde eeuwgetijde in hun oorspronkelijken vorm herdrukt (The Hague: Nijhoff, 1874).

Anonymous, Een waerachtig verhael van schermutsinghe by die van Leyden opten xxix julij 1574 jeghen den viandt ghehouden, in R.J. Fruin, J.E.H. Hooft van Iddekinge and W.J.C. Rammelman Elsevier (eds), De oude verhalen van het Beleg en Ontzet van Leiden bij gelegenheid van het derde eeuwgetijde in hun oorspronkelijken vorm herdrukt (The Hague: Nijhoff, 1874).

Anonymous, Iovrnal. Ander Theil zusatz vnd Anhang des gantzen Journals vber die treffliche vnd weitberumte Belägerung der statt vnd Kriegs Vniversiteit Ostende in Flandern (s.l.: s.n., 1604).

Anonymous, Nievwe chroniicke oft Verhael van alle de gedenckweerdichste saken die geschiet zijn, t'sedert den iare 1500. tot [...] 1624 (Antwerp: Godtgaf Verhulst, 1624). 
Anonymous, Tweede deel van de Spieghel der Spaensche tyrannye, gheschiet in Nederland (Amsterdam: Jan Evertsz. Cloppenburgh, 1620).

Antonio, F., Auisos para soldados y gente de guerra (Madrid: P. Madrigal, 1590).

Antunes, Emanuel, Primera parte de la baxada de los españoles de Francia en Normandía (Rouen: George Lóyselet, 1593).

Antunes, Emanuel, Primera parte de la baxada de los españoles de Francia en Normandía (Antwerp: Giraldo Wolsschatio, 1622).

Ardant du Picq, Charles, Etudes sur le combat. Combat antique et combat moderne (Paris: Economica, 2004, 4th edn 1904).

Arnade, Peter, Beggars, Iconoclasts, and Civic Patriots. The Political Culture of the Dutch Revolt (Ithaca: Cornell University Press, 2008).

Assmann, Aleida, 'Canon and archive', in Astrid Erll and Ansgar Nünning (eds), Cultural Memory Studies: An International and Interdisciplinary Handbook (Berlin and New York: Walter de Gruyter, 2010), pp. 97-107.

Assmann, Aleida, 'Re-framing memory. Between individual and collective forms of constructing the past', in Karin Tilmans, Frank van Vree and Jay Winter (eds), Performing the Past: Memory, History, and Identity in Modern Europe (Amsterdam: Amsterdam University Press, 2010), pp. 35-50.

Asten, A.F.N. van, 'De gevangenschap van Heezenaren te Heerentals in 1580', in De Comme geopend. Geschiedkundige opstellen uit de Kempen (Eindhoven 1983), pp. 86-92.

Bachiler, S., The Campe Royal, Seth forth in briefe meditations on the words of the Prophet Moses, Deut. 23.9.14. hereunder following, preached in the Army (Amsterdam: R.P., 1629).

Bailey, A., Velázquez and the Surrender of Breda: the Making of a Masterpiece (New York: Henry Holt and Co., 2011).

Baudartius, Willem, Morghen-wecker der vrye Nederlantsche Provintien. Ofte / een cort verhael van de bloedighe vervolginghen ende wreetheden door de Spaenjaerden ende hare Adherenten inde Nederlanden / gheduerende dese veertich-jarighe Troublen ende Oorloghen begaen aen vele Steden / ende ettelijcke duysent particuliere Personen ([Danzig]: Crijn Vermeulen de Jonge, 1610).

Baudartius, Willem, Afbeeldinghe, ende beschrijvinghe van alle de veld-slagen, belegeringen, ende and're notable geschiedenissen, ghevallen in de Nederlanden, geduerende d'oorloghe teghens den coningh van Spaengien or De Nassausche oorloghen (Amsterdam: Michiel Colijn, 1616).

Been, J., 'Krijgsgevangenen ten tijde van de Republiek', Vragen van de dag, 31 (1916), 10-11.

Begheyn, P., Jesuit Books in the Dutch Republic and its Generality Lands 1567-1773 (Leiden and Boston: Brill, 2014).

Belägerung der Statt Ostende. Iovrnal Dritter vnd letster theill des gantzenn Journals vber die treffeliche vnd weith bervmbte belägerung der Statt vnd Kriegs-Vniversiteit Ostende in Flandern (s.l.: s.n., 1605).

Beller, Manfred and Joep Leerssen (eds), The Cultural Construction and Literary Representation of National Characters. A Critical Survey (Amsterdam: Rodopi, 2007). 
Belleroche, Edward, The Siege of Ostend or the New Troy, 1601-1604 (London: Spottiswoode, 1892).

Benedict, Philip, Graphic History. The Wars, Massacres and Troubles of Tortorel and Perrissin (Geneva: Droz, 2007).

Benedict, Philip, Guido Marnef, Henk van Nierop and Marc Venard (eds), Reformation, Revolt and Civil War in France and the Netherlands 1555-1585 (Amsterdam: Koninklijke Nederlandse Akademie van Wetenschappen, 1999).

Bentivoglio, Guido, Relationi fatte dall'ill.mo, e rev.mo sig.or cardinal Bentivoglio in tempo delle sue nuntiature di Fiandra, e di Francia. Date in luce da Erycio Puteano (Antwerp: Jan van Meerbeeck, 1629).

Bentivoglio, Guido, Relationi fatte dall'ill.mo, e rev.mo sig.or cardinal Bentivoglio. Date in luce da Erycio Puteano (Cologne: Nicolao Pantino, 1629).

Bentivoglio, Guido, Della Guerra di Fiandra, vol. 1 (Cologne, Rome, 1632-39).

Berco, Cristian, Sexual Hierarchies, Public Status. Men, Sodomy, and Society in Spain's Golden Age (Toronto: University of Toronto Press, 2007).

Berkovich, Ilya, Motivation in War. The Experience of Common Soldiers in Old-Regime Europe (Cambridge and New York: Cambridge University Press, 2017).

Bernard, Mathilde, Écrire la peur à l'épôque des guerres de religion. Une étude des historiens et mémorialistes contemporaines des guerres civiles de France, 1562-1598 (Paris: Hermann, 2010).

Bernard, R., The Bible-Battels, or the Sacred Art Military for the rightly wageing of warre according to Holy Writ (London: Edward Blackmore, 1629).

Bertini, Giuseppe, 'Carriere di militari italiani nell' esercito di Alessandro Farnese nei Paesi Bassi: merito o privilegio', in Giuseppe Bertini (ed.), Militari italiani dell'esercito di Alessandro Farnese nelle Fiandre (Fidenza: Mattioli 1885, 2013), pp. 171-203.

Bireley, R., The Counter-Reformation Prince. Anti-Machiavellianism or Catholic Statecraft in Early Modern Europe (Chapel Hill: The University of North Carolina Press, 1990), pp. 162-87.

Bocchi, Francesco, Historia della ribellione della Fiandra, avvenuta sotto la corona del Re Cattolico, Filippo di Spagna (Archivio di Stato di Firenze. Carte Strozziane, Prima serie n. 275).

Boehm, Christopher, 'The biocultural evolution of conflict resolution between groups', in Douglas P. Fry (ed.), War, Peace and Human Nature. The Convergence of Evolutionary and Cultural Views (Oxford and New York: Oxford University Press, 2013), pp. 315-40.

Bolland, Johannes et al., Imago primi saeculi Societatis Iesu a Provincia Flandro-Belgica eiusdem Societatis repraesentata (Antwerp: ex officina Plantiniana Balthasaris Moreti, anno Societatis Saeculari 1640).

Boltanski, A. et al. (eds), La Bataille. Du fait d'armes au combat idéologique XIe-XIXe siècle (Rennes: Presses Universitaires de Rennes, 2015).

Boltanski, A., 'Forger le "soldat chrétien". L'encadrement catholique des troupes pontificales et royales en France en 1568-1569’, Revue Historique, 669 (2014), $51-85$ 
Boltanski, A., 'A Jesuit "missio castrensis" in France at the End of the Sixteenth Century: Discipline and Violence at War', Journal of Jesuit Studies, 4 (2017), 581-98.

Bom, E. de, 'Carolus Scribani and the Lipsian legacy: the "Politico-Christianus" and Lipsius's image of the good prince', in E. de Bom et al. (eds), (Un)masking the Realities of Power. Justus Lipsius and the Dynamics of Political Writing in Early Modern Europe (Leiden and Boston: Brill, 2010), pp. 281-306.

Bor, Pieter, Oorspronck, begin ende aenvang der Nederlantschen oorlogen en beroerten ende Borgerlijcke oneenicheyden (The Hague: Beuckel Cornelisz. Nieulandt, 1603).

Bor, Pieter, Den oorspronck, begin ende aenvanck der Nederlandtscher oorlogen, geduyrende de regeringe van de Hertoginne van Parma, de Hertoge van Alba, ende eensdeels vanden groot Commandeur / beschreven door Pieter Bor Chistiaenszoon, ende nu deur denselven in liedekens vervaet (Leiden: Govert Basson, 1617).

Bor, Pieter, Oorsprongh, begin, ende vervolgh der Nederlantsche Oorloghen (s.l.: s.n., 1621).

Bor, Pieter, Oorspronck, begin ende vervolgh der Nederlantsche oorlogen, 5 vols (Leiden: Govert Basson and Amsterdam: Michiel Colijn, 1621-34).

Bor, Pieter, Oorsprongk, begin ende vervolgh der Nederlandsche oorlogen, beroerten, en borgerlyke oneenigheden, 4 vols (Amsterdam 1679-84).

Borja de Medina, F. de, 'Jesuitas en la armada contra Inglaterra (1588). Notas para un centenario', Archivum Historicum Socetatis Iesu, 58 (1989), 3-41.

Borreguero Beltrán, Cristina, 'Philip of Spain; the spider's web of news and information', in Brendan Maurice Dooley (ed.), The Dissemination of News and the Emergence of Contemporaneity in Early Modern Europe (Farnham and Burlington: Ashgate, 2010), pp. 23-50.

Bourdeille, Pierre de, Oeuvres complètes de Pierre de Bourdeille seigneur de Brantôme, ed. Ludovic Lalanne (Paris: 1864-82).

Bouza, Fernando, Corre manuscrito. Una historia cultural del Siglo de Oro (Madrid: Marcial Pons, 2001).

Bouza, Fernando, 'El pueblo desea las noticias. Relaciónes de sucesos y gacetas entre propaganda y esfera pública en la España de los Austrias', in Cuatro siglos de noticias en cien años (Madrid: Hemeroteca Municipal, 2018), pp. 113-43.

Bouza, Fernando, Del Escribano a la Biblioteca. La civilización escrita europea en la alta edad moderna (siglos XV-XVII) (Madrid: Ediciones Akal, 2018).

Breen, J.C., 'Gereformeerde populaire historiographie in de zeventiende en achttiende eeuw', Tijdschrift voor Geschiedenis, 37 (1922), 254-73 and 372-82.

Brouwer, Johan, Kronieken van Spaansche soldaten uit het begin van den Tachtigjarigen Oorlog (Zutphen: W.J. Thieme, 1933).

Brouwers, L. and J.F. Gilmont, Carolus Scribani (Brussels: Bibliotheca Belgica, 1977).

Brouwers, L., 'L'“Elogium” du père Thomas Sailly S.I. (1553-1623) composé par le père Charles Scribani S.I.', Archivum Historicum Societatis Iesu, 48 (1979), 87-124.

Brown, J., Velázquez: Painter and Courtier (New Haven: Yale University Press, 1986).

Brunelli, G., Soldati del papa. Politica militare e nobiltà nello Stato della Chiesa (1560-1644) (Rome: Carocci, 2003). 
Burke, Peter, and R. Po-Chia Hsia (eds), Cultural Translation in Early Modern Europe (Cambridge: Cambridge University Press, 2007).

Burmania, Poppo van, Enege gedenckwerdege geschiedenissen. Kroniek van de Friese militair Poppo van Burmania uit de Tachtigjarige Oorlog, ed. Wiebe Bergsma (Hilversum: Verloren, 2012)

Cabrera de Córdoba, L., Historia de Felipe II, Rey de España, eds J. Martínez Millán and C.J. de Carlos Morales (Valladolid: Junta de Castilla y León, 1998).

Calendar of State Papers Foreign: Elizabeth, 23 vols (London: Her/His Majesty's Stationery Office, 1863-1950).

Callard, Caroline, Le Prince et la République. Histoire, pouvoir et société dans la Florence des Médicis au XVIIe siècle (Paris: Presses de la Université Paris-Sorbonne, 2007).

Callewier, H. (ed.), Inventaris van het archief van de Nederduitse Provincie der Jezuïeten (Provincia Belgica, vervolgens Provincia Flandro-Belgica) en van het archief van het professenhuis te Antwerpen (1388) 1564-1773 (Brussels: Algemeen Rijksarchief, 2006).

Campana, Cesare, Della guerra di Fiandra fatta pe difesa di Religione da Cattolici Re di Spagna Filippo II e Filippo III di tal nome, 2 vols (Vicenza: Giorgio Greco, 1602).

Campene, Cornelis and Philip van, Dagboek van Cornelis en Philip van Campene behelzende het verhaal der merkwaardigste gebeurtenissen, voorgevallen te Gent sedert het begin der Godsdienstberoerten tot den 5en april 1571, ed. Frans de Potter (Gent: C. Annoot-Braeckman, 1870).

Carlos Bertrán, Luis de, Alexander. La extraordinaria historia de Alejandro Farnesio (Barcelona: Editorial Crítica, 2018).

Caro, Rodrigo, Memorial de la Villa de Utrera: autor el licenciado Rodrigo Caro (Sevilla: El mercantil sevillano, 1883).

Carrasco, Rafael, Inquisición y represión sexual en Valencia. Historia de los sodomitas (1565-1785) (Barcelona: Laertes, 1985).

Cascales, Francisco, Cartas filológicas (Murcia: Luis Verós, 1634).

Chagnon, Napoleon, Noble Savages. My Life among two Dangerous Tribes: the Yanomamö and the Anthropologists (New York and London: Simon \& Schuster, 2013).

Cillessen, Wolfgang, 'Massaker in der niederländischen Erinnerungskultur: Die Bildwerdung der Schwarzen Legende', in Christine Vogel (ed.), Bilder des Schreckens. Die mediale Inszenierung von Massakern seit dem 16. Jahrhundert (Frankfurt am Main and New York: Campus Verlag, 2006), pp. 93-135.

Civale, G. Guerrieri di Cristo. Inquisitori, gesuiti e soldati alla battaglia di Lepanto (Milano: Unicolpi, 2009).

Civale, G., 'Tunisi spagnola tra violenza e coesistenza (1573-74)', Mediterranea: Ricerche storiche, 21 (2011), 51-88.

Civale, G., 'Francesco Borgia e gli esordi della pastorale gesuitica nei confronti dei soldati (1565-1572)', in E. García Hernán (ed.), Francisco de Borja y su tiempo, 1510-1572. Política, religión y cultura en la Edad Moderna (Rome and Valencia: IHSI, 2012), pp. 207-22.

Civale, G., 'La Compagnia di Gesù, la guerra e l'immagine del soldato da Ignazio a Possevino (1546-1569)', Società e Storia, 140 (2013), 283-317. 
Claramonte y Corroy, Andrés de, El valiente negro en Flandes, ed. Ana Ogallas Moreno (Würzburg and Madrid: Clásicos Hispánicos, 2016).

Cogswell, Th., The Blessed Revolution. English Politics and the Coming of War, 1621-1624 (Cambridge and New York: Cambridge University Press, 1989).

Colección de Documentos Inéditos para la Historia de España, 113 vols (Madrid: Academia de la Historia, 1842-1895).

Coloma de Saa, Carlos, Las Guerras de los Estados Baxos desde el año de M.D.LXXXVIII hasta el de M.D.XCIX (Antwerp: Pedro and Juan Bellero, 1624).

Coloma de Saa, Carlos, 'Las guerras de los Estados-Bajos, desde el año 1588 hasta el de 1599', in Biblioteca de autores españoles, historiadores de sucesos particulares, 28:2 (Madrid: Real Academia Española, 1948), pp. 4-203.

Conestaggio, Gerolamo, Dell'unione del regno di Portogallo alla corona di Castiglia (Genoa: Girolamo Bartoli, 1585).

Conestaggio, Gerolamo, Historia de la union del reyno de Portugal, a la corona de Castilla (Barcelona: Sebastian de Cormellas, 1610).

Conestaggio, Gerolamo, Delle Guerre della Germania Inferiore (Venice: Antonio Pinelli, 1614).

Conestaggio, Gerolamo, Historia delle guerre della Germania Inferiore (Leiden: Bonaventura and Abraham Elzevier, 1634).

Cornejo, Pedro, Della historia di Fiandra, di Pietro Cornelio libri X: nella quale si vede l'origine delle civili dissensioni .... con la descrittione di tutto quel paese (Brescia: Pietro Maria Marchetti, 1582).

Correspondance de Christophe Plantin, ed. J. Denucé (Nendel: Kraus Reprint, 1968, 1st edn, 1918).

Correspondance de Guillaume le Taciturne, ed. L.P. Gachard, 6 vols (Brussels, Leipzig and Ghent: C. Muquardt, 1850-57).

Correspondance de Philippe II sur les affaires des Pays-Bas, eds Louis-Prosper Gachard and Joseph Lefèvre, 6 vols (Brussels: Mucquardt, Librairie ancienne et moderne, 1848-1936).

Corvisier, André, L'Armée française de la fin du XVIIième siècle au ministère de Choiseul. Le soldat (Paris: Presses Universitaires de France, 1964).

Costa, Marco, Psicologia militare. Elementi di psicologia per gli appartenenti alle forze armate (Milan: F. Angeli, 2003).

Covarrubias Orozco, Sebastián de, Tesoro de la lengua castellana o española, eds Felipe C.R. Maldonado and Manuel Camarero (Madrid: Castalia, 1995).

Cox, B., Vanden Tocht in Vlaenderen. De logistiek van Nieuwpoort, 1600 (Zutphen: De Walburg Pers, 1986).

Cubitt, Geoffrey, History and Memory (Manchester: Manchester University Press, 2013).

De Lucca, D., Jesuits and Fortifications. The Contribution of the Jesuits to Military Architecture in the Baroque Age (Leiden and Boston: Brill, 2012).

De Vos, Luc, 'Het Beleg van Oostende, 1601-1604', in Luc De Vos (ed.), Veldslagen in de Lage Landen (Leuven: Davidsfonds, 1995), pp. 79-87.

Deen, Femke, Publiek debat en propaganda in Amsterdam tijdens de Nederlandse Opstand. 
Amsterdam 'Moorddam' 1566-1578 (Amsterdam: Amsterdam University Press, 2015).

Derks, Sebastiaan, 'Reconstrucciones de una Reconquista. Léon van der Essen y el ejército español de los Países Bajos', in Léon van der Essen, El ejército español en Flandes 1567-1584, ed. Gustaaf Janssens (Cuacos de Yuste: Fundación Academia Europea de Yuste, 2008), pp. 27-44.

Dietz, F. et al. (eds), Illustrated Religious Texts in the North of Europe, 1500-1800 (Farnham: Ashgate, 2014).

Dietz, F., 'Dark images, clear words: Pieter Paets's illustrated devotional literature from Mission Hollandica', in K. Enenkel and W.S. Melion (eds), Meditatio: Refashioning the Self (Leiden and Boston: Brill, 2010), pp. 291-320.

Dijk, Teun van, 'Episodes as units of discourse analysis', in Deborah Tannen (ed.), Analyzing Discourse: Text and Talk (Georgetown: Georgetown University Press, 1982), pp. 177-95.

Dorsman, Leen, 1600: Slag bij Nieuwpoort (Hilversum: Verloren, 2000).

Duerloo, Luc, 'Dynastieke vroomheid en herbouw van het vorstelijk gezag', Bijdragen en Mededelingen betreffende de Geschiedenis der Nederlanden, 112:1 (1997), 1-18.

Duerloo, Luc, Dynasty and Piety: Archduke Albert (1598-1621) and Habsburg Political Culture in an Age of Religious Wars (Farnham: Ashgate, 2012).

Duke, Alastair, 'In defence of the common fatherland. Patriotism and liberty in the Low Countries, 1555-1576', in Robert Stein and Judith Pollmann (eds), Networks, Regions and Nations. Shaping Identities in the Low Countries, 1300-1650 (Leiden and Boston: Brill, 2010), pp. 217-40.

Dunthorne, Hugh, Britain and the Dutch Revolt 1560-1700 (Cambridge: Cambridge University Press, 2013).

Duyck, Anthonis, Journaal van Anthonis Duyck, Advokaar-fiscaal van den Raad van State 1591-1602, ed. Lodewijk Mulder (The Hague and Arnhem: Martinus Nijhoff and D.A. Thieme, 1864).

Eekhout, Marianne, 'Material memories of the Dutch Revolt. The urban memory landscape in the Low Countries, 1566-1700' (PhD thesis, Universiteit Leiden, Leiden, 2014).

Elias, H.J., Kerk en staat in de Zuidelijke Nederlanden onder de regeering der aartshertogen Albrecht en Isabella (1598-1621) (Antwerp: De Sikkel, 1931).

Ellis, S.G and R.M. Esser (eds), Frontier and Border Regions in Early Modern Europe (Hannover: Wehrhahn Verlag, 2013).

Epistolario del III Duque de Alba, Don Fernando Álvarez de Toledo, ed. Duque de Alba, 3 vols (Madrid: Diana, 1952).

Epithafia in Serenissimum Alexandrum Farnesium (Coloniae Agrippinae: Arnoldus Mylius, 1598).

Erll, Astrid, 'Cultural memory studies: An introduction', in Astrid Erll and Ansgar Nünning (eds), A Companion to Cultural Memory Studies (Berlin and New York: Walter de Gruyter, 2010), pp. 1-15.

Espino López, Antonio, Guerra y cultura en la época moderna (Madrid: Ministerio de Defensa, 2001). 
Essen, Léon van der, 'Documents concernant le vicaire général Francisco de Umara et l'organisation religieuse de l'armée espagnole aux Pays-Bas pendant les guerres de Flandre (1597-1599)', Analectes pour Servir a I'Histoire Ecclésiastique de la Belgique, 37 (1911), 263-81.

Essen, Léon van der, Alexandre Farnèse: prince de Parme, gouverneur général des Pays-Bas, 1545-1592, 5 vols (Brussels: Librairie Nationale d'Art et d'Histoire et al., 1933-37).

Evans, P.S., The Invasion of Sennacherib in the Book of Kings: a Source-critical and Rhetorical Study of 2 Kings 18-19 (Leiden: Brill, 2009).

Eysenck, Hans, Crime and Personality (St Albans: Routledge \& Kegan Paul, 1964, revised edn, 1977).

Fagel, Raymond, Leids Beleg en Ontzet door Spaanse ogen (Den Haag: Sdu Uitgevers, 1998). Fagel, Raymond, 'Julián, un héroe Español en Flandes: entre el príncipe de Orange y el duque de Alba', in René Vermeir, Maurits Ebben and Raymond Fagel (eds), Agentes e identidades en movimiento España y los Países Bajos siglos XVI-XVIII (Madrid: Silex, 2011), pp. 271-88.

Fagel, Raymond, Kapitein Julián. De Spaanse held van de Nederlandse Opstand (Hilversum: Verloren, 2011).

Fagel, Raymond, 'Describir la guerra. Narrativas de la primera década de las guerras de Flandes, 1567-1577', in Enrique García Hernán and Davide Maffi (eds), Estudios sobre guerra y sociedad en la Monarquía Hispánica. Guerra marítima, estrategia, organización y cultura militar 1500-1700 (Valencia: Albatros Ediciones, 2017), pp. 507-18.

Fagel, Raymond, 'Gascoigne's The Spoyle of Antwerpe (1576) as an Anglo-Dutch Text', Dutch Crossing, 41 (2017), 101-10.

Fagel, Raymond, De Spaanse belegeraar van Leiden. Het eigen verhaal van Francisco de Valdés (Leiden: Primavera Pers, 2017).

Fagel, Raymond, and Joke Spaans, Nonnen verdreven door geuzen, Cathalina del Spiritu Sancto's verhaal over de vlucht van Nederlandse clarissen naar Lissabon (Hilversum: Verloren, 2019).

Faini, Marco, and Maria Elena Severini (eds), Books for Captains and Captains in Books. Shaping the Perfect Military Commander in Early Modern Europe (Wiesbaden: Harrassowitz Verlag, 2016).

Fasano Guarini, Elena, and Franco Angiolini (eds), La pratica della storia in Toscana: continuità e mutamenti tra la fine del ' 400 e la fine del '700 (Milan: Franco Angeli, 2009).

Fernández Álvarez, Manuel, Tres embajadores de Felipe II en Inglaterra (Madrid: Consejo Superior de Investigaciones Científicas, 1951).

Fernández Conti, Santiago, 'La profesionalización del gobierno de la guerra: Don Alonso de Vargas', in José Martínez Millán (ed.), La corte de Felipe II (Madrid: Alianza, 1994), pp. 417-50.

Fineman, Joel, 'The history of the anecdote: fiction and fiction', in H. Aram Veeser (ed.), The New Historicism (New York and London: Taylor \& Francis, 1989), pp. 49-76. 
Finot, Jules, 'Les subventions accordées aux Litterateurs, au Savants et aux Artistes par les Gouverneurs des Pays-Bas au XVIIe siècle relevées dans les comptes de la recette générale des finances', Annales du Comité Flamand de France, 19 (1891), 179.

Fludernik, Monika, Towards a 'Natural' Narratology (London and New York: Routledge, 1996).

Fludernik, Monika, 'Letters and chronicles: How narrative are they?', in Göran Rossholm (ed.), Essays on Fiction and Perspective (Bern and Oxford: Peter Lang, 2004), pp. 129-53.

Fra Molinero, Baltasar, 'Ser mulato en España y América: discursos legales y otros discursos literarios', in Berta Ares Queija and Alessandro Stella (eds), Negros, mulatos, zambaigos. Derroteros africanos en los mundos ibéricos (Sevilla: Escuela de Estudios Hispano-Americanos, Consejo Superior de Investigaciones Científicas, 2000), pp. 123-47.

Fruin, R.J., J.E.H. Hooft van Iddekinge and W.J.C. Rammelman Elsevier, De oude verhalen van het Beleg en Ontzet van Leiden bij gelegenheid van het derde eeuwgetijde in hun oorspronkelijken vorm herdrukt (The Hague: Nijhoff, 1874).

Fruytiers, J., Corte beschryvinghe vande strenghe belegheringhe ende wonderbaerlicke verlossinghe der stadt Leyden in Hollandt (Delft, 1574), in R.J. Fruin, J.E.H. Hooft van Iddekinge and W.J.C. Rammelman Elsevier, De oude verhalen van het Beleg en Ontzet van Leiden bij gelegenheid van het derde eeuwgetijde in hun oorspronkelijken vorm herdrukt (The Hague: Nijhoff, 1874).

Fruytiers, J., Corte beschrijuinghe van de strenghe belegheringhe ende wonderbaerlijcke verlossinghe der stadt Leyden in Hollandt (Delft, 1577), in R.J. Fruin, J.E.H. Hooft van Iddekinge and W.J.C. Rammelman Elsevier, De oude verhalen van het Beleg en Ontzet van Leiden bij gelegenheid van het derde eeuwgetijde in hun oorspronkelijken vorm herdrukt (The Hague: Nijhoff, 1874).

Fumaroli, M., 'Baroque et classicisme. L'Imago Primi Saeculi Societatis Jesu' (1640) et ses adversaries', in M. Fumaroli, L'école du silence. Le sentiment des images au XVIIe siècle (Paris: Flammarion, 1994), pp. 343-65.

Gaillard, A. (ed.), Inventaire sommaire des archives de la Compagnie de Jésus conservées aux Archives Générales du Royaume à Bruxelles (Brussels: Archives Générales du Royaume, 1910).

García Cárcel, Ricardo, El demonio del sur. La Leyenda Negra de Felipe II (Madrid: Cátedra, 2017).

García Hernán, David, La cultura de la guerra y el teatro del Siglo de Oro (Madrid: Silex, 2006).

García Hernán, E., 'Capellanes militares y Reforma Católica', in E. García Hernán and D. Maffi (eds), Guerra y sociedad en la Monarquía Hispánica. Política, estrategia y cultura en la Europa moderna (1500-1700) (Madrid: Mapfre, 2006), vol. 2.

García-Arenal Rodríguez, Mercedes and Fernando Rodríguez Mediano (eds), The Orient in Spain. Converted Muslims, the Forged Books of Granada, and the Rise of Orientalism (Leiden and Boston: Brill, 2013).

Gascoigne, George, The Complete Works of George Gascoigne, ed. J.W. Cunliffe (Cambridge: Cambridge University Press, 1910). 
Gat, Azar, 'The causes of war in natural and historical evolution', in Henrik Høgh-Olesen (ed.), Human Morality and Sociality. Evolutionary and Comparative Perspectives (Basingstoke and New York: Palgrave and Macmillan, 2010), pp. 160-90.

Geevers, Liesbeth, Gevallen vazallen. De integratie van Oranje, Egmont en Horn in de Spaans-Habsburgse monarchie (1559-1567) (Amsterdam: Amsterdam University Press, 2008).

Gelderen, Martin van, The Political Thought of the Dutch Revolt 1555-1590 (Cambridge: Cambridge University Press, 1992).

Génard, Pierre, La Furie Espagnole: documents pour servir à l'histoire du sac d'Anvers en 1576 (Antwerp: G. van Merlen, 1876).

Geurts, P.A.M., De Nederlandse Opstand in de pamfletten 1566-1584 (Nijmegen: Centrale Drukkerij, 1956).

Geurts, P.A.M., De Nederlandse Opstand in de pamfletten 1566-1584 (Utrecht: HES Publishers, 1978).

Ghiglieri, Michael P., The Dark Side of Man. Tracing the origins of male violence (Cambridge, MA: Perseus Books, 2000).

Gietman, Conrad, Republiek van adel. Eer in de Oost-Nederlandse adelscultuur (15551702) (Utrecht: Van Gruting, 2010).

Giustiniani, Pompeo, Delle Guerre di Fiandra Libri VI (Antwerp: Ioachimo Trognesio, 1609).

Gómez Dovale, María América, 'Una fuente inédita sobre la guerra de Flandes' (PhD thesis, Universidad Complutense de Madrid, 1957).

González de León, Fernando, 'Doctors of the military discipline; technical expertise and the paradigm of the Spanish soldier in the Early Modern Period', Sixteenth Century Journal, 27:1 (1996), 61-85.

González de León, Fernando, The Road to Rocroi. Class, Culture and Command in the Spanish Army of Flanders 1567-1659 (Leiden and Boston: Brill, 2009).

González Ollé, Fernando, 'Guerras civiles de Flandes. Poema épico inédito', Boletín de la Real Academia de la Historia, 45 (1965), 141-84.

Goosens, Pieter, 'De slag bij Nieuwpoort in 1600, vanuit een Zeeuws logistiek perspectief' (MA thesis, Universiteit Gent, 2007).

Gouge, W., The Dignitie of Chivalry, Set forth in a Sermon, preached before the Artillery Company of London, Iune. XIII. 1626. (London: G.M. for Ralph Mab, 1626).

Gracián, G., El soldado catholico, que prueva con historia, exemplos y razones claras [...] que los que no tienen letras, no han de disputar de la fee con los hereges; abomina las heregias de nuestros tiempos, y loa la Yglesia Romana (Brussels: Roger Velpio y Huberto Antonio, 1611).

Gramaye, Jean-Baptiste, Gallo-Brabantia (Brussels: Jan Mommaert, 1606).

Gré Ponce, Dennis Francisco, 'La moral y la guerra: los cronistas de Flandes: expresión de la cultura política de la Monarquía Hispánica, siglos XVI y XVII' (PhD thesis, Universidad de Granada, 2015).

Grever, Maria, 'Nationale identiteit en historisch besef. De risico's van een canon in de postmoderne samenleving', Tijdschrift voor Geschiedenis, 119:2 (2006), $160-77$. 
Griffiths, Gordon, William of Hornes, Lord of Hèze and the Revolts of the Netherlands (1576-1580) (Berkeley: University of California Press, 1954).

Grimeston, Edward, A Trve History of the Memorable Siege of Ostend (London: Edward Blount, 1604).

Groof, B. de, 'A noble courtier and a gentleman warrior: Some aspects of the creation of the Spinola image', in J. Fenoulhet and L. Gilbert (eds), Narratives of Low Countries. Reframing the Past (London: University College of London Press, 2016), pp. 26-34.

Grossman, Dave and Loren W. Chistensen, On Combat. The Psychology and Physiology of Deadly Conflict in War and Peace (Mascoutah, IL: PPCT Research Publications, 2004).

Grossman, Dave, On Killing. The Psychological Cost of Learning to Kill in War and Society (Boston and London: Little, Brown, 1995).

Gysius, Johannes, Oorsprong en voortgang der Neder-landtscher beroerten ende ellendicheden (Leiden: Henrick Lodewijcxsoon Haestens, 1616).

Haecht, Godevaert van, De kroniek van Godevaert van Haecht over de troebelen van 1565 tot 1574 te Antwerpen en elders I, ed. Rob van Roosbroeck (Antwerp: De Sikkel, 1929).

Haer, Florentius van der, De initiis tumultuum belgicorum ad Serenissimum D.D. Alexandrum Farnesium Parmae et Placentiae Ducem Libri Duo (Douai: Johannes Bogardus, 1587).

Haestens, Henrick van, De bloedige ende strenge belegeringhe der Stadt Oostende in Vlaenderen [...] (Leiden: Henrick van Haestens, 1613).

Haestens, Henrick van, La Nouvelle Troye ou memorable histoire du Siege d'Ostende (Leiden: Louis Elzevier, 1615).

Haitsma Mulier, E.O.G., 'Grotius, Hooft and the writing of history in the Dutch Republic', in A.C. Duke and C.A. Tamse (eds), Clio's Mirror. Historiography in Britain and the Netherlands (Zutphen: De Walburg Pers, 1985), pp. 55-72.

Hale, John R., War and Society in Renaissance Europe, 1450-1620 (Baltimore: Johns Hopkins University Press, 1985).

Hale, John R., War and Society in Renaissance Europe. 1450-1620 (Montreal: McGillQueen's University Press, 1998).

Hanlon, Gregory, The Twilight of a Military Tradition. Italian Aristocrats and European Conflicts, 1560-1800 (New York: Holmes \& Meier, 1998).

Hanlon, Gregory, The Hero of Italy. Odoardo Farnese, Duke of Parma, his Soldiers, and his Subjects in the Thirty Years' War (Oxford: Oxford University Press, 2014).

Hanlon, Gregory, Italy 1636: Cemetery of Armies (Oxford: Oxford University Press, 2016).

Haraeus, Franciscus, Onpartijdighe verclaringhe der oorsaken des Nederlantsche oorloghs sedert t'iaer 1566. tot 1608 (Antwerp: Gheleyn Ianssens, 1612).

Harari, Yuval Noah, Renaissance Military Memoirs. War, History, and Identity, 1450-1600 (Woodbridge: Boydell \& Brewer, 2004).

Harari, Yuval Noah, The Ultimate Experience. Battlefield Revelations and the Making of Modern War Culture, 1450-2000 (Basingstoke and New York: Palgrave, 2008).

Hardie, Iain, Dominic Johnson and Dominic Tierney, 'Psychological aspects of war', 
in Christopher J. Coyne and Rachel L Mathers (eds), The Handbook on the Political Economy of War (Cheltenham and Northampton, MA: Edward Elgar Publishing, 2011), pp. 72-92.

Hart, Marjolein 't, The Dutch Wars of Independence. Warfare and Commerce in the Netherlands, 1570-1680 (London: Routledge, 2014).

Harward, S., The Solace for the Souldier and Saylor (London: Thomas Orwin for Thomas Wight, 1592).

Henriksen, Rune, 'Warriors in combat - what makes people actively fight in combat', The Journal of Strategic Studies, 30 (2007), 187-223.

Heuser, Beatrice (ed.), Small Wars and Insurgencies in Theory and Practice, 1500-1850 (Abingdon: Routledge, 2016).

Hill, Christopher, The World Turned Upside Down. Radical Ideas During the English Revolution (New York: Penguin Books, 1975).

Hobsbawm, Eric, 'Introduction: inventing traditions', in Eric Hobsbawm and Terence Ranger (eds), The Invention of Tradition (Cambridge: Cambridge University Press, 2000, first published in 1983), pp. 1-14.

Hooft, P.C., Alle de gedrukte werken 1611-1738, eds W. Hellinga and P. Tuynman (Amsterdam: Amsterdam University Press, 1972).

Hopper, Andrew, Turncoats and Renegadoes. Changing sides During the English Civil Wars (Oxford: Oxford University Press, 2012).

Hopperus, Joachim, 'Recueil et mémorial des troubles des Pays Bas du Roy, 1559 1566', in Alphonse Wauters (ed.), Mémoires de Viglius et d'Hopperus sur le commencement des troubles des Pays-Bas avec notices et annotations (Brussels: Wauters, 1858).

Hortal Muñoz, José Eloy, Los asuntos de Flandes (Saarbrücken: Lambert Academic Publishing GmbH \& Co., 2011).

Hugo, H., Pia Desideria (Antwerp: Hendrick Aertssens, 1624).

Hugo, H., Sitio de Breda rendida a las armas del Rey Don Phelipe IV a la virtud de la infante doña Isabel, al valor del marques Ambr. Spinola (Antwerp: ex Off. Plantiniana B. Moreti, 1627).

Hugo, H., De militia equestri antiqua et nova libri quinque (Antwerp: ex Off. Plantiniana B. Moreti, 1630).

Hugo, H., Sitio de Breda rendida a las armas del Rey Don Phelipe IV a la virtud de la infante doña Isabel, al valor del marques Ambr. Spinola, ed. Julio Albi de la Cuesta (Madrid: Balkan, 2001).

Israel, Jonathan, The Dutch Republic. Its Rise, Greatness, and Fall, 1477-1806 (Oxford: Clarendon Press, 1995).

Janssen, A.E.M., 'A “Trias Historica” on the revolt of the Netherlands: Emanuel van Meteren, Pieter Bor and Everhard van Reyd as exponents of contemporary historiography', in A.C. Duke and C.A. Tamse (eds), Clio's Mirror. Historiography in Britain and the Netherlands (Zutphen: De Walburg Pers, 1985), pp. 9-30.

Janssens, Gustaaf, Brabant in het verweer. Loyale oppositie tegen Spanje's bewind in de Nederlanden van Alva tot Farnese 1567-1578 (Kortijk and Heule: Standen en Landen, 1989). 
Janssens, Gustaaf, 'Alva en de Nederlanden (16de-21ste eeuw). Een biografische en historiografische benadering van een berucht historisch personage', in Judith Brouwer and Michael Limberger (eds), Hedendaagse biografieën over vroegmoderne lieden (Leuven: Universitaire Pers Leuven, 2018), pp. 35-55.

Jensen, Lotte, De verheerlijking van het verleden. Helden, literatuur en natievorming in de negentiende eeuw (Nijmegen: Vantilt, 2008).

Jensen, Lotte (ed.), The Roots of Nationalism. National Identity Formation in Early Modern Europe, 1600-1815 (Amsterdam: Amsterdam University Press, 2016).

Kattenberg, Lisa, 'Military rebellion and reason of state. Pacification of mutinies in the Habsburg army of Flanders, 1599-1601', BMGN-Low Countries Historical Review, 131:2 (2016), 3-21.

Keegan, John, A History of Warfare (New York: Random House, 1993).

Kelly, Raymond C., Warless Societies and the Origins of War (Ann Arbor: University of Michigan Press, 2000).

Kloek, E., Kenau \& Magdalena: Vrouwen in de Tachtigjarige Oorlog (Nijmegen: Vantilt, 2014).

Kooij, Barbara (ed.), Spaanse ooggetuigen over het beleg van Haarlem, 1572-1573 (Hilversum: Verloren, 2018).

Koppenol, J., Het Leids Ontzet. 3 oktober 1574 door de ogen van tijdgenoten (Amsterdam: Athenaeum-Polak \& Van Gennep. 2002).

Krusenstjern, Benigna von, Selbstzeugnisse der Zeit des Dreissigjährigen Krieges: beschreibendes Verzeichnis (Berlin: Akademie Verlag, 1997).

Krusenstjern, Benigna von and Hans Medick (eds), Zwischen Alltag und Katastrophe. Der Dreißigjährige Krieg aus der Nähe (Göttingen: Vandenhoeck \& Ruprecht, 1999).

Kuijpers, Erika et al. (eds), Memory before Modernity. Practices of Memory in Early Modern Europe (Leiden and Boston: Brill, 2013).

Lamal, Nina, 'Le orecchie si piene de Fiandra. Italian news and histories on the Revolt of the Netherlands' (PhD thesis, Universiteit Leuven, Leuven, 2014).

Lamal, Nina, 'Promoting the Catholic cause on the Italian peninsula. Printed Avvisi on the Dutch Revolt and the French Wars of Religion, 1562-1600', in Joad Raymond and Noah Moxham (eds), News Networks in Early Modern Europe (Leiden and Boston: Brill, 2016), pp. 675-94.

Lanario, Francesco, Le guerre di Fiandra brevemente narrate (Antwerp: Geronimo Verdussen, 1615).

Las Casas, Bartolomé de, Brevíssima relación de la destruyción de las Indias (Seville: s.n., 1552).

Las Casas, Bartolomé de, Spieghel der Spaenscher tyrannye, in West Indien (Amsterdam: Nicolaes Biestkens de Jonghe, 1596).

Las Casas, Bartolomé de, The Tears of the Indians: being an Historical and true Account of the Cruel Massacres and Slaughters of above Twenty Millions of innocent People; committed by the Spaniards in the Islands of Hispaniola, Cuba, Jamaica, \&c. As also, in the Continent of Mexico, Peru, \&other Places of the West-Indies, to the total destruction of those Countries (London: Nath. Brook, 1656).

Lavenia, V., 'In God's Fields. Military chaplains and soldiers in Flanders during the 
Eighty Years' War', in M. Mondini and M. Rospocher, Narrating War. Early Modern and Contemporary Perspectives (Bologna and Berlin: Il Mulino-Duncker \& Humblot, 2013), pp. 99-112.

Lavenia, V., Dio in uniforme. Cappellani, catechesi cattolica e soldati in età moderna (Bologna: Il Mulino, 2017).

Lavenia, V., 'Jesuit catechisms for soldiers (XVII-XIX centuries): Changes and continuities', Journal of Jesuit Studies, 4 (2017), 599-623.

Leeuwen, J. van (ed.), It aade Friesche Terp of Kronyk der Geschiedenissen van de Vrye Friesen (Leeuwarden: J. Proost, 1834).

Lefèvre, J., 'L'aumônerie militaire à l'époque de l'archiduc Albert (1598-1621)', Revue Belge de Philologie et d'Histoire, 7 (1928), 113-29.

Leighton, A., Speculum belli sacri: Or The looking-glasse of the holy war wherein is discovered: the evill of war. The good of warr. The guide of war ([Amsterdam]: Giles Thorp. 1624).

Lem, Anton van der, Revolt in the Netherlands. The Eighty Years War, 1568-1648 (London: Reaktion Books, 2018).

Levin, Michael J., Agents of Empire. Spanish Ambassadors in Sixteenth-century Italy (Ithaca and London: Cornell University Press, 2005).

Lipsius, Justus, Diva Virgo Hallensis (Antwerp: ex officina Plantiniana, apud Ioannem Moretum, 1604).

Lombaerde, Piet, 'De stad Oostende en de nieuwe gebastioneerde versterkingswijzen in de Nederlanden', in Werner Thomas (ed.), De val van het Nieuwe Troje. Het beleg van Oostende, 1601-1604 (Leuven: Davidsfonds, 2004), pp. 47-57.

Lombaerde, Piet, 'Oostende afgesneden, belegerd, opgegeven en ingenomen: 1599 1604', in Dirk de Vries (ed.), Oostende verloren Sluis gewonnen, 1604. Een kroniek in kaarten (Leiden: Universiteitsbibliotheek, 2004), pp. 47-69.

Londoño, Sancho de, Discurso sobre la forma de reducir la disciplina militar a meyor y antiguo estado (Brussels: Rutger Velpius, 1589).

Lorenz, Chris, 'Unstuck in time. Or: the sudden presence of the past', in Karin Tilmans, Frank van Vree and Jay Winter (eds), Performing the Past: Memory, History and Identity in Modern Europe (Amsterdam: Amsterdam University Press, 2010), pp. 78-80.

Machielsen, J., 'Friendship and religion in the Republic of Letters: the return of Justus Lipsius to Catholicism (1591)', Renaissance Studies, 27 (2011), 161-82.

Mancarella, Angelo, Antropologia dello Stato e della Guerra. Tra vecchio e nuovo evoluzionismo (Rome: Laicata, 2004).

Mansfelt, C. de, Castra Dei, sive Parochia, Religio et Disciplina Militum (Brussels: apud Martinum de Bossuyt, 1642).

Martín García, Gonzalo, Sancho Dávila, soldado del rey (Ávila: Institución Gran Duque de Alba, 2010).

Martin, Brian, Napoleonic Friendship. Military Fraternity, Intimacy, and Sexuality in Nineteenth-Century France (Durham: University of New Hampshire Press, 2011).

Martínez Luna, Fernando, Een ondraaglijk juk. Nederlandse beeldvorming van Spanje en de Spanjaarden ten tijde van de Opstand 1566-1609 (Hilversum: Verloren, 2018). 
Martínez, Miguel, Front Lines. Soldiers' Writing in the Early Modern Hispanic world (Philadelphia: University of Pennsylvania Press, 2016).

Mazzatinti, Giuseppe, Inventari dei manoscritti delle biblioteche d'Italia (Forli: Luigi Bordandini, 1895), vol. 5.

Mazzocchi, G., 'Nel testo del Discurso di Sancho de Londoño. Note bibliografiche ed ecdotiche', in Giovanni Caravaggi (ed.), La espada y la pluma. Il mondo militare nella Lombardia spagnola cinquecentesca (Viareggio, Lucca: Mauro Baroni, 2000), pp. 563-79.

Medick, H., 'The Thirty Years' War as experience and memory: Contemporary perceptions of a macro-historical event', in L. Tatlock (ed.), Enduring Loss in Early Modern Germany. Cross Disciplinary Perspectives (Leiden: Brill, 2010), pp. $25-49$.

Meijer Drees, M., 'Vaderlandse heldinnen in belegeringstoneelstukken', De Nieuwe Taalgids, 85 (1993), 71-82.

Mendoza, Bernardino de, Comentarios de las guerras de los Países Bajos, in Biblioteca de autores españoles XXVIII, Historiadores de sucesos particulares II (Madrid: Real Academia Española, 1948).

Mendoza, Bernardino de, Comentarios de don Bernardino de Mendoça de lo sucedido en las guerras de los Países Baxos, desde el año de 1567 hasta el de 1577, eds A. Cortijo Ocaña and A. Gómez Moreno (Madrid: Ministerio de Defensa, 2008).

Mensema, A.J., J.S. Mooijweer and J.C. Streng, De Ridderschap van Overijssel. Le Métier du Noble (Zwolle: Waanders Uitgeverij, 2000).

Meteren, E. van, Belgische ofte Nederlandsche historie van onsen tijden (Delft: Jacob Cornelisz. Vennecool, 1599).

Meteren, E. van, Commentarien ofte Memorien van-den Nederlandtschen staet, handel, oorloghen ende gheschiedenissen van onsen tyden, etc. Mede vervattende eenige haerder ghebueren handelinghen (Scotland: Hermes van Loven, 1608).

Meteren, E. van, Historie der Neder-landscher ende haerder na-buren oorlogen ende geschiedenissen (The Hague: by Hillebrant Iacobssz van Wouw, 1614).

Milton, John, Paradise Lost, eds Stephen Orgel and Jonathan Goldberg (Oxford: Oxford University Press, 1991).

Moffit, J.F., 'Diego Velázquez, Andrea Alciati and the Surrender of Breda', Artibus et Historiae, 5 (1982), 75-90.

Mondini, Marco, 'Narrated wars. Literary and iconographic stereotypes in historical accounts of armed conflict', in Marco Mondini and Massimo Rospocher (eds), Narrating War. Early Modern and Contemporary Perspectives (Bologna and Berlin: Il Mulion and Duncker \& Humblot, 2013), pp. 11-28.

Montes, Diego, Instrucción y regimiento de guerra (Zaragoza: Jorge Coci, 1537).

Moretti, S., 'La trattatistica italiana e la guerra. Il conflitto tra la Spagna e le Fiandre (1566-1609)', Annali dell'Istituto storico italo-germanico in Trento, 20 (1994), 129-64.

Morford, M., Stoics and Neostoics. Rubens and the Circle of Lipsius (Princeton: Princeton University Press, 1991).

Mörke, Olaf, 'The content, form and function of Swiss and Dutch images of history', 
in André Holenstein, Thomas Maissen and Maarten Prak (eds), The Republican Alternative. The Netherlands and Switzerland Compared (Amsterdam: Amsterdam University Press, 2009).

Morrill, John, 'Mutiny and discontent in English provincial armies, 1645-1647', Past \& Present, 56 (1972), 49-75.

Mortimer, Geoff, Eyewitness Accounts of the Thirty Years War, 1618-1648 (Basingstoke: Palgrave Macmillan, 2004).

Mostaccio, S., 'La mission militaire jésuite auprès de l'armée des Flandres pendant la guerre de Trente Ans. Conversions et sacrements', in B. Forclaz and Ph. Martin (eds), Religion et pieté au défi de la guerre de Trente Ans (Rennes: Presses Universitaires de Rennes, 2015), pp. 183-202.

Mostaccio, S., 'Genere e guerra. Genere in guerra? Storia e storie intorno all' esercito delle Fiandre. Una proposta', in M. Caffiero, M.P. Donato and G. Fiume (eds), Donne, potere, religione. Studi per Sara Cabibbo (Milano: FrancoAngeli, 2017), pp. 51-66.

Müller, Johannes, Exile Memories and the Dutch Revolt. The Narrated Diaspora, 15501750 (Leiden and Boston: Brill, 2016).

Munz, Peter, 'The historical narrative', in Michael Bentley (ed.), Companion to Historiography (London and New York: Routledge, 1997), pp. 851-72.

Murray, John J., Antwerp in the Age of Plantin and Brueghel (Newton Abbot: David \& Charles, 1972).

Nierop, Henk van, 'Alva's throne. Making sense of the Revolt of the Netherlands', in Graham Darby (ed.), The Origins and Development of the Dutch Revolt (London and New York: Routledge, 2001), pp. 29-47.

Nierop, Henk van, Treason in the Northern Quarter (Princeton: Princeton University Press, 2009).

Nischan, Bodo, 'On the edge of the abyss', in Geoffrey Parker (ed.), The Thirty Years War, 2nd edn (New York and London: Routledge, 1984/1997), pp. 100-8.

Nix, J.C., 'De Atlas Van Stolk: Een verzameling historieprenten over de vaderlandse geschiedenis', Ons Erfdeel, 39 (1996), 233-40.

O’Malley, J.W. (ed.), Art, Controversy and the Jesuits. 'The Imago Primi Saeculi Societatis Iesu' (Philadelphia: Saint Joseph's University Press, 2015).

Orange, William of, Verklaeringhe ende wtschrifft des duerluchtighsten, hoochgeborenen vorsten ende heeren, heer Willem, Prince van Oranien, etc. ende zijner excellentien nootsakelicken defensie teghen den duca de Alba, ende zijne grouwelicke tyrannie (s.l.: s.n., 1568).

Orange, William of, Willem byder gratien Gods prince van Orangien, grave toe Nassau, Catzenellenbogen, Vianden, Dietz, \&c. heere baron toe Bredae [...] Allen ghetrouwen ondersaten des Con. Mai. in den Nederlanden, saluyt (s.l.: s.n., 1568).

Orange, William of, De verantvvoordinghe des princen van Orangien, teghen de valsche loghenen, daer mede sijn vvedersprekers hem soecken t'onrechte te beschuldighen (s.l.: s.n., 1568).

Orange, William of, The apologie or defence, of $[\ldots]$ prince William $[\ldots]$ prince of Orange [...] against the proclamation [...] by the king of Spaine (Delft: s.n., 1581). 
Orlers, Jan Janszoon and Henrick van Haestens, Den Nassauschen lauren-crans (Leiden: Orlers and Van Haestens, 1610).

Otterbein, Keith, The Anthropology of War (Long Grove, IL: Waveland Press, 2009).

Palazzolo, C., Il soldato di Santa Chiesa per l'institutione alla pietà de i cento mila fanti \& de i diece mila soldati a cavallo delle Militie dello Stato Ecclesiastico [...] co'l regolamento di dette militie (Rome: Luigi Zanetti, 1606).

Parker, Geoffrey, The Army of Flanders and the Spanish Road, 1567-1659. The logistics of Spanish victory and defeat in the Low Countries' wars (Cambridge: Cambridge University Press, 1972, 1984, 2nd edn, 2004).

Parker, Geoffrey, 'Mutiny and discontent in the Spanish Army of Flanders 15721607', Past and Present, 58 (1973), 38-52.

Parker, Geoffrey, The Dutch Revolt (Ithaca, NY: Cornell University Press, 1977).

Parker, Geoffrey, The Dutch Revolt (London: Allen Lane, 1977).

Parker, Geoffrey, 'Mutiny and discontent in the Spanish army of Flanders, 15721607', in Geoffrey Parker, Spain and the Netherlands 1559-1659. Ten Studies (London: Collins, 1979), pp. 106-21.

Parker, Geoffrey, The Dutch Revolt (Harmondsworth: Penguin, 1979).

Parker, Geoffrey, '1630-1632: The intervention of Sweden', in Geoffrey Parker (ed.), The Thirty Years War, 2nd edn (New York and London: Routledge, 1984/1997), pp. 108-19.

Parker, Geoffrey, The Military Revolution. Military Innovation and the Rise of the West 1500-1800 (Cambridge: Cambridge University Press, 1988, 1996).

Parker, Geoffrey, 'Soldados del imperio. El ejército español y los Países Bajos en los inicios de la Edad Moderna', Werner Thomas and Robert A. Verdonk (eds), Encuentros en Flandes. Relaciones e intercambios hispano-flamencos a comienzos de la Edad Moderna (Leuven: Leuven University Press/Fundación Duques de Soria, 2000), pp. 275-90.

Parker, Geoffrey, Empire, War and Faith in Early Modern Europe (London: Allen Lane, the Penguin Press, 2002).

Parker, Geoffrey, Felipe II: la biografía definitiva (Barcelona: Planeta, 2013).

Parrilla Hermida, M., El hospital militar español de Malinas en los siglos XVI y XVII (Madrid: Ministerio del Ejército, 1964).

Paul Ricoeur, Time and Narrative (Chicago and London: University of Chicago Press, 1984).

Pazzis Pi Corrales, Magdalena de, 'La “comisión” del capitán Francisco de Eraso a Suecia: una posible alternativa al conflicto con Flandes', in José Martínez Millán (ed.), Felipe II, 1527-1598. Europa y la Monarquía Católica (Madrid: Parteluz, 1998), vol. 2:2, pp. 617-33.

Périer, Jérémie, Continuation des sieges d'Ostende, et de l'Escluse, auec le portrait des nouueaux retranchement [sic] d'Ostende (Paris, 1604).

Périer, Jérémie, Histoire remarqvable et veritable de ce qvi s'est passé par chacun iour au siege de la ville d'Ostende, de part \& d'autre iusques à present (Paris: Ieremie Perier, 1604).

Philadelphe Cosmopolite, Eusebe, Der Francoysen ende haerder naeghebueren Morghenwecker 
[...] Ghemaeckt door Eusebius Philadelphus; ouergheset door Jan Fruytiers (Dordrecht: Jan Canin, 1574).

Philadelphe Cosmopolite, Eusebe, Le reveille-matin des Francois, et de leurs voisins ([Edinburgh]: Jacques James, 1574).

Piceu, Tim, Over vrybuters en quaetdoenders. Terreur op het Vlaamse platteland (eind 16de eeuw) (Leuven: Davidsfonds, 2008).

Pieper, Renate, 'News from the New World: Spain's monopoly in the European network of handwritten newsletters during the sixteenth century', in Raymond and Moxham (eds), News Networks, pp. 495-511.

Pimentel, Pedro Alfonso, Guerras civiles de Flandes, ed. María América Gómez Dovale, in 'Una fuente inédita sobre la guerra de Flandes' (PhD thesis, Universidad Complutense de Madrid, 1957).

Pintacuda, Paolo, 'Sobre las dos versiones del Sitio y toma de Amberes de Miguel Giner', in Paolo Pintacuda (ed.), Le vie dell'epica ispanica (Lecce: Pensa Multimedia, 2014), pp. 95-122.

Pintacuda, Paolo, 'El hereje desde la "épica de la pólvora". Los rebeldes de Flandes vistos por los tercios españoles', in Javier Burguillo López (ed.), Épica y conflicto religioso en el siglo XVI. Anglicanismo y luteranismo desde el imaginario hispánico (London: Tamesis, in press).

Pocock, J.G.A., The Machiavellian Moment. Florentine Political Thought and the Atlantic Republican Tradition (Princeton, Princeton University Press, 1975).

Pollmann, Judith, 'Eine natürliche Feindschaft. Ursprung und Funktion der Schwarzen Legende über Spanien in den Niederlanden, 1560-1581', in Franz Bosbach (ed.), Feindbilder. Die Darstellung des Gegners in der politischen Publizistik des Mittelalters und der Neuzeit (Cologne and Weimar: Böhlau, 1992), pp. 73-93.

Pollmann, Judith, 'Countering the Reformation in France and the Netherlands. Clerical leadership and Catholic violence 1560-1585', Past and Present, 190 (2006), 83-120.

Pollmann, Judith, "Brabanters do fairly resemble Spaniards after all". Memory, propaganda and identity in the Twelve Years' Truce', in Judith Pollmann and Andrew Spicer (eds), Public Opinion and Changing Identities in the Early Modern Netherlands. Essays in Honour of Alastair Duke (Leiden and Boston: Brill, 2007), pp. 219-24.

Pollmann, Judith, Herdenken, herinneren, vergeten. Het Beleg en Ontzet van Leiden in de Gouden Eeuw (Leiden: Primavera Pers, 2008).

Pollmann, Judith, 'Internationalisering van de Nederlandse Opstand', BMGN-Low Countries Historical Review, 124:4 (2009), 515-35.

Pollmann, Judith, 'No man's land. Reinventing Netherlandish identities, 15851621', in Robert Stein and Judith Pollmann (eds), Networks, Regions and Nations. Shaping Identities in the Low Countries, 1300-1650 (Leiden and Boston: Brill, 2010), pp. 253-60.

Pollmann, Judith, Catholic Identity and the Revolt of the Netherlands, 1520-1635 (Oxford: Oxford University Press, 2011). 
Pollmann, Judith, Memory in Early Modern Europe, 1500-1800 (Oxford: Oxford University Press, 2017).

Pollmann, Judith and Erika Kuijpers, 'Introduction. On the early modernity of modern memory', in Erika Kuijpers et al. (eds), Memory Wars. Practices of Memory in Early Modern Europe (Leiden and Boston: Brill, 2013), pp. 1-23.

Poncelet, A., Histoire de la Compagnie de Jésus dans les ançiens Pays-Bas (Brussels: Academie Royale de Belgique, 1927), vol. 2.

Possevino, A., Il soldato christiano con l'instruttione dei capi dello essercito catolico (Roma: Dorici, 1569).

Puddu, Raffaele, Il soldato gentiluomo. Autoritratto d'una società guerriera: La Spagna del Cinquecento (Bologna: Il Molino, 1982).

Puteanus, Erycius, Miracles derniers de Nostre Dame de Montaigv (Leuven: Hendrik van Hastens and Petrus II Zangrius, 1622).

Raymond, Joad and Noah Moxham (eds), News Networks in Early-modern Europe (Leiden and Boston: Brill, 2016).

Reardon, Bernard M.G., Religious Thought in the Reformation, 2nd edn (London: Longman, 1995).

Reijner, Cees, 'Een Italiaanse verdediger van de Opstand? De internationale controverse rond het werk van Gerolamo Conestaggio', Tijdschrift voor Geschiedenis, 125:2 (2012), 172-87.

Reijner, Cees, 'Il mito dell'Olanda. Politiek en geschiedschrijving in vroegmodern Italië', Incontri, 30:2 (2015), 41-55.

Rey de Artieda, Andrés, Discursos, epístolas y epigramas de Artemidoro, ed. Antonio Vilanova (Barcelona: Selecciones Bibliófilas, 1955).

Reyd, E. van, Voornaemste gheschiedenissen inde Nederlanden ende elders beschreven (Arnhem: Ian Iansz, 1626).

Rigney, Ann, The Rhetoric of Historical Representation. Three Narrative Histories of the French Revolution (Cambridge: Cambridge University Press, 1990).

Rodríguez Hernández, Antonio José, Los tercios de Flandes (Madrid: Nowtilus, 2015).

Rodríguez Pérez, Yolanda, 'Alonso Vázquez en Johan Brouwer. Een zestiendeeeuwse Spaanse militair en zijn twintigste-eeuwse vertaler', Armada, 38 (March 2005), 10-17.

Rodríguez Pérez, Yolanda, The Dutch Revolt through Spanish Eyes: Self and Other in Historical and Literary Texts of Golden Age Spain (c.1548-1673) (Oxford and Bern: Peter Lang, 2008).

Rodríguez Pérez, Yolanda, 'El amotinado como español ejemplar. Rojas Zorilla y Los amotinados de Flandes de Vélez de Guevara', in Eugenia Houvenaghel, Ilse Logie (ed.), Alianzas entre historia y ficcion. Homenaje a Patrick Collard (Genève: Droz, 2009), pp. 237-48.

Rodríguez Pérez, Yolanda, 'G. de Bay: un traductor de Cervantes del siglo XVII como agente de la memoria histórica neerlandesa', in René Vermeir, Maurits Ebben and Raymond Fagel (eds), Agentes e identidades en movimiento. España y los Países Bajos, siglos XVI-XVIII (Madrid: Sílex, 2011), pp. 403-22.

Rodríguez Pérez, Yolanda, Antonio Sánchez Jiménez and Harm den Boer (eds), 
España ante sus críticos: las claves de la Leyenda Negra (Madrid and Frankfurt am Main: Iberoamericana and Vervuert, 2015).

Rodríguez, Pedro, and Justina Rodríguez (eds), Don Francés de Alava y Beamonte. Correspondencia inédita de Felipe II con su embajador en París (1564-1570) (Donostia-

San Sebastián: Instituto Dr. Camino de Historia Donostiarra, 1991.

Rodríguez Alva, Cristóbal, 'La inquieta Flandes' (1594), Biblioteca Nacional de España, MSS/22648.

Rodríguez-Salgado, M.J., 'Il Capo dei Capi: the Duke of Alba in Italy', in Maurits Ebben, Margriet Lacy-Bruijn and Rolfo van Hövell tot Westerflier (eds) Alba. General and Servant to the Crown (Rotterdam: Karwansaray Publishers, 2013), pp. 226-55

Rödter, G.D., 'Via piae animae'. Grundlagenuntersuchung zur emblematischen Verknüpfung von Bild und Wort in den 'Pia desideria' (1624) des Hermann Hugo S.J. (1588-1629) (Frankfurt am M.: Peter Lang, 1992).

Rooms, Et., 'Een nieuwe visie op de gebeurtenissen die geleid hebben tot de Spaanse Furie te Antwerpen op 4 november 1576', Bijdragen tot de geschiedenis, 1:2 (1971), 31-55.

Rosen, Stephen Peter, War and Human Nature (Princeton and Oxford: Princeton University Press, 2005).

Ruiz Ibáñez, José Javier and Gabriela Vallejo Cervantes, 'Furia y virtud: la narrativa de masacre en las crónicas de Flandes', in Antonio Jiménez Estrella et al. (eds), Construyendo historia. Estudios en torno a Juan Luis Castellano (Granada: Universidad de Granada, 2013), pp. 667-77.

Ruiz Martín, F., 'El pan de los países bálticos durante las guerras de religión. Andanzas y gestiones del historiador Pedro Cornejo', Hispania, 21:84 (1961), 3-33.

Rutte, Reinout and Bram Vannieuwenhuyze, Stedenatlas Jacob van Deventer. 226 Stadsplattegronden uit 1545-1575 - Schakels tussen verleden en heden (Bussum and Tielt: Thoth/Lannoo, 2018).

Rutz, A. (ed.), Krieg und Kriegsführung im Westen des Reiches 1568-1714 (Göttingen: Vandenhoeck \& Ruprecht, 2016).

Sailly, T., Guidon et practique spirituelle du soldat chrestien reveu \& augmenté pour l'armee de sa M.tè Catholique au Pays-bas (Antwerp: en l'Imprimerie Plantinienne, 1590).

Sailly, T., In obitum serenissimi Alexandri Farnesii Parmae, et Placentiae Ducis (Mediolani: apud Franciscum Paganellum, 1595).

Sailly, T., Den nievwen morghen-vvecker, wijsende de natuere [...] der ketterije (Leuven: Joannes Christophorus Flavius, 1612).

Sailly, T., Memorial testamentaire composé en faveur des soldats, premiere première (Leuven: chez Henri Hastens, 1622).

Salazar y Castro, Luis de, Historia genealogica de la Casa de Silva, 2 vols (Madrid, 1685). Salcedo Ruiz, Ángel, El coronel Cristóbal de Mondragón apuntes para su biografía. (Madrid: Marceliano Tabarés, 1905).

Salviucci Insolera, L., L'Imago primi saeculi (1640) e il significato dell'immagine allegorica nella Compagnia di Gesù. Genesi e fortuna del libro (Rome: Pontificia Università Gregoriana, 2004). 
Santiago Belmonte, Beatriz, 'La correspondencia de los comandantes militares españoles como fuente para el estudio de las guerras de Flandes (1567-1577)', in Enrique García Hernán and Davide Maffi (eds), Estudios sobre guerra y sociedad en la monarquía hispánica: guerra marítima, estrategia, organización y cultura militar (1500-1700) (Valencia: Albatros, 2017), pp. 623-38.

Sapolsky, Robert M., Behave. The Biology of Humans at our Best and Worst (New York: Penguin Press, 2017).

Schama, Simon, The Embarrassment of Riches: An Interpretation of Dutch Culture in the Golden Age (London: Collins, 1987).

Scheelings, F.G., 'De geschiedschrijving en de beeldvorming over de Opstand in de Zuidelijke Nederlanden (16e-18e eeuw)', in J. Craeybeckx et al. (eds), 1585: op gescheiden wegen. Handelingen van het colloquium over de scheiding der Nederlanden, gehouden 22-23 november 1985 te Brussel (Leuven: Peeters, 1988), pp. 151-79.

Schele, Sweder, 'Stambuchs', NLA - Staatsarchiv Osnabrück. Dep. 38b. N. 1000.

Schele, Sweder, 'Huiskroniken offte Stamboecks', Dep. Huisarchief Almelo. Inv. N. 3680.

Schepper, Hugo de, 'Un catalán en Flandes: don Luis de Requesens y Zuñiga, 15731576', Pedralbes: Revista d'historia moderna, 18:2 (1998), 157-67.

Schepper, Hugo de,'Belgium Nostrum' 1500-1650. Over integratie en desintegratie van het Nederland (Antwerp: De Orde van den Prince, 1987).

Schmidt, Benjamin, Innocence Abroad. The Dutch Imagination and the New World, 15701670 (Cambridge: Cambridge University Press, 2001).

Schoonbrood, M. and J.S. Grossier, Schetsen uit de geschiedenis van Maastricht en omstreken (Nieuwendijk: De Forel, 1972).

Schoonjans, J., “'Castra Dei”. L'organisation religieuse des armées d'Alexandre Farnèse', in Miscellanea historica in honorem Leonis van der Essen (Brussels and Paris: Éditions Universitaires, 1947), pp. 523-40.

Schuermans, H., 'La colonne de Culembourg à Bruxelles', Bulletin des commissions royales d'art et d'archéologie (1870), 17-107.

Scott, Th., The Belgick Souldier, or Warre was a Blessing (Dordrecht: s.n., 1624).

Sherer, Idan, “'All of us, in one voice, Demand what's owed us”: Mutiny in the Spanish Infantry during the Italian Wars, 1525-1538', Journal of Military History, 78 (2014), 893-926.

Sherer, Idan, Warriors for a Living. The Experience of the Spanish infantry in the Italian Wars, 1494-1559 (Leiden and Boston: Brill, 2017).

Simoni, Anna, 'Henrick van Haestens from Leiden to Leuven via "Cologne", Quaerendo, 15/3 (1985), 187-94.

Simoni, Anna, The Ostend Story. Early Tales of the Great Siege and the Mediating Role of Henrick van Haestens ('t Goy-Houten: HES \& De Graaf, 2003).

Smith, Leonard V., The Embattled Self. French Soldiers' Testimony of the Great War (Ithaca and London: Cornell University Press, 2007).

Soen, Violet, 'Reconquista and reconciliation in the Dutch Revolt: The campaign of Governor-General Alexander Farnese (1578-1592)', Journal of Early Modern History, 16 (2012), 1-22. 
Soen, Violet, Vredehandel. Adellijke en Habsburgse verzoeningspogingen tijdens de Nederlandse Opstand 1564-1581 (Amsterdam: Amsterdam University Press, 2012).

Soen, Violet et al., 'How to do transregional history: A concept, method and tool for Early Modern border research', Journal of Early Modern History, 21:6 (2017), pp. 355-6.

Spagnoletti, Angelantonio, 'Quale patriottismo per i soldati napoletani al servizio della Monarchia Cattolica?', in Enrique García Hernán and Davide Maffi (eds), Guerra y Sociedad en la Monarquía Hispánica: Política, Estrategia y Cultura en la Europa Moderna (1500-1700), vol. II (Madrid: Ediciones del Laberinto, 2006), pp. 163-77.

Spagnoletti, Angelantonio, 'Onore e spirito nazionale nei soldati italiani al servizio della monarchia spagnola', in Claudio Donati and Bernhard R. Kroener (eds), Militari e società civile nell'Europa dell'età moderna (secoli XVI-XVIII) (Bologna: Il Mulino, 2007), pp. 211-53.

Spiritu Sancto, Cathalina del, Relacion de como se ha fundado en Alcantara de Portugal junto a Lisboa, el muy devoto monasterio de Nuestra Señora de la Quietacion (Lisbon: Pedro Craesbeeck, 1627).

Steen, Jasper van der, Memory Wars in the Low Countries, 1566-1700 (Leiden and Boston: Brill, 2015).

Steen, Jasper van der, 'Remembering the Revolt of the Low Countries: historical canon formation in the Dutch Republic and Habsburg Netherlands, 15661621', The Sixteenth Century Journal, 49:3 (2018), 713-41.

Stensland, Monica, Habsburg Communication in the Dutch Revolt (Amsterdam: Amsterdam University Press, 2012).

Strada, Famiano, Della guerra di Fiandra, deca prima (Rome: Hermann Scheus, 1638).

Sugg, Richard, Mummies, Cannibals, and Vampires. The History of Corpse Medicine from the Renaissance to the Victorians (Abingdon: Routledge, 2015).

Sutton, Imogen, “'De gente que a ningún rey obedecen”. Republicanism and Empire in Alonso de Ercilla's La Araucana', Bulletin of Hispanic Studies, 91:4 (2014), 417-35.

Swart, Erik, Krijgsvolk. Militaire professionalisering en het ontstaan van het Staatse leger, 1568-1590 (Amsterdam: Amsterdam University Press, 2006).

Swart, Erik, 'Defeat, honour and the news. The case of the fall of Breda', European History Quarterly, 46 (2016), 6-26.

Swart, K.W., 'The Black Legend during the Eighty Years War', in J.S. Bromley and E.H. Kossmann (eds), Britain and the Netherlands V: Some Political Mythologies (The Hague: Martinus Nijhoff, 1975), pp. 36-57.

Swart, K.W., William of Orange and the Revolt of the Netherlands, 1572-1584 (Aldershot: Ashgate, 2003).

Tallett, Frank, War and Society in Early Modern Europe (London: Routledge, 1992).

Tezcan, Baki, The Second Ottoman Empire. Political and Social Transformation in the Early Modern World (Cambridge: Cambridge University Press, 2010).

Thomas, Werner, Een spel van kat en muis. Zuidnederlanders voor de Inquisitie in Spanje, 
1530-1750, Verhandelingen van de Koninklijke Academie voor wetenschappen, Letteren en Schone Kunsten van België, Klasse der Letteren 53:140 (Brussels: Koninklijke Academie, 1991).

Thomas, Werner, 'Het beleg van Oostende', in Werner Thomas (ed.), De val van het Nieuwe Troje. Het beleg van Oostende, 1601-1604 (Leuven: Davidsfonds, 2004), pp. 81-99.

Thomas, Werner, De val van het nieuwe Troje. Het beleg van Oostende 1601-1604 (Leuven: Davidsfonds, 2004).

Thomas, Werner, 'Jerónimo Gracián de la Madre de Dios, la corte de Bruselas y la política religiosa en los Países Bajos meridionales, 1607-1614', in R. Vermeir et al. (eds), Agentes e identidades en movimiento. España y los Países Bajos, siglos XVI-XVII (Madrid: Sílex, 2011), pp. 289-313.

Tinbergen, Nikko, 'On War and Peace in animals and man. An ethologist's approach to the biology of aggression', Science, 160:3835 (1968), 1411-18.

Tjoelker, N., 'Jesuit image rhetoric in Latin and vernacular. The Latin and Dutch emblems of the "Imago Primi Saeculi”", Rencessanceforum, 6 (2010), 97-118.

Tooby, John and Leda Cosmides, 'The evolution of war and its cognitive foundations', Institute for Evolutionary Studies Technical Report, 88:1 (1988), 5-10.

Torre, Lucas de, 'Los motines militares en Flandes', Revista de Archivos, Bibliotecas y museos, 25-32 (1911-15).

Torsellini, O., Vida de San Francisco Xavier [...] traduzida en Romance por el P. Pedro de Guzman (Pamplona: Labàyen, 1620).

Tracy, James D., The Founding of the Dutch Republic: War, Finance, and Politics in Holland, 1572-1588 (Oxford: Oxford University Press, 2008).

Trillo, Antonio, Historia de la rebelión y guerras de Flandes, ed. M.A. Echevarría Bacigalupe (Vienna and Munich: Verlag für Geschichte und Politik and R. Oldenbourg Verlag, 2008).

Trim, D.J.B. (ed.), The Chivalric Ethos and the Development of Military Professionalism (Leiden and Boston: Brill, 2003).

Trim, D.J.B., 'Introduction', in D.J.B. Trim (ed.), The Chivalric Ethos and the Development of Military Professionalism (Leiden and Boston: Brill, 2003).

Trim, D.J.B., 'Ideology, greed, and social discontent in Early Modern Europe. Mercenaries and mutinies in the rebellious Netherlands, 1568-1609', in Jane Hathaway (ed.), Rebellion, Repression, Reinvention. Mutiny in Comparative Perspective (Westport, CT: Praeger, 2007), pp. 47-62.

Trouillot, Michel-Rolph, Silencing the Past. Power and the Production of History (Boston: Beacon Press, 1995).

Ubachs, P.J.H and Ingrid Evers, Historische Encyclopedie Maastricht (Zutphen: Walburg Pers, 2005).

Verbeek, Peter, 'An ethological perspective on War and Peace', in Douglas P. Fry (ed.), War, Peace and Human Nature. The Convergence of Evolutionary and Cultural Views (Oxford and New York: Oxford University Press, 2013), pp. 54-77.

Verdugo, Francisco, Voor God en mijn koning. Het verslag van kolonel Francisco Verdugo over zijn jaren als legerleider en gouverneur namens Filips II in Stad en lande van 
Groningen, Drenthe, Friesland, Overijssel en Lingen (1581-1595), ed. Jan van den Broek (Assen: Van Gorcum, 2009)

Vermaseren, B.A., De katholieke Nederlandse geschiedschrijving in de 16e en 17e eeuw over de Opstand (Leeuwarden: Gerben Dykstra, 1981).

Vermeulen, Joos, 'Rebels Oostende. Weergalm en naklank', in Werner Thomas (ed.), De val van het Nieuwe Troje. Het beleg van Oostende, 1601-1604 (Leuven: Davidsfonds, 2004), pp. 127-37.

Verstegan, Richard, De spiegel der Nederlandsche elenden. / Getoont door een lief-hebber der waerheyt ende der Nederlanden welvaert (Mechelen: Hendrick Iaye, 1621).

Vivo, Filippo de, Information and Communication in Venice. Rethinking Early-modern Politics (Oxford: Oxford University Press, 2007).

Vlietinck, Edward, Het oude Oostende en zijne driejarige belegering (1601-1604). Opkomst, bloei en ondergang, met de beroerten der XVIe eeuw (Oostende: Jos Vlietinck, 1897).

Voges, Ramon, Das Auge der Geschichte. Der Aufstand der Niederlande und die Französischen Religionskriege im Spiegel der Bildberichte Franz Hogenbergs (ca. 1560-1610) (Leiden and Boston: Brill, 2019).

Vosters, S.A., La rendición de Bredá en la literatura y el arte de España (London: Tamesis, 1973).

Vranck, François, Wederlegghinghe, van een seker boecxken, uyt ghegheven by Franchois Verhaer, ghenaemt Onpartijdighe verclaringhe der oorsaken vande Nederlantsche oorloghe (Breda: Steven Wylicx, 1618).

Waal, Frans de, Peacemaking among Primates (Cambridge, MA: Harvard University Press, 1989).

Westrin, Th. (ed.), Nordisk Familjebok. Konversationslexicon och Realenencyclopedi, Fjortonde Bandet (Stockholm: Nordisk familjeboks förlags, 1911).

White, Hayden, Metahistory. The Historical Imagination in Nineteenth-century Europe (Baltimore and London: Johns Hopkins University Press, 1973).

White, J., Militant Protestantism and British Identity 1603-1642 (New York: Routledge, 2012).

Williams, Roger, The Actions of the Low Countries, ed. D.W. Davies (Ithaca, NY: Cornell University Press, 1964).

Wilson, Peter H., The Thirty Years War. Europe's Tragedy (Cambridge, MA: The Belknap Press of Harvard University Press, 2009).

Win, P. de, De schandstraffen in het wereldlijk strafrecht in de Zuidelijke Nederlanden van de Middeleeuwen tot de Franse Tijd bestudeerd in Europees perspectief (Brussels: Paleis der Academiën, 1991).

Wintringham, Tom H., Mutiny. Being a Survey of Mutinies from Spartacus to Invergordon (New York: Fortuny's, 1936).

Woltjer, J.J., 'Dutch privileges, real and imaginary', in J.S. Bromley and E.H. Kossmann (eds), Britain and the Netherlands V: Some Political Mythologies (The Hague: Martinus Nijhoff, 1975), pp. 19-35.

Wright, Robert, Nonzero. The Logic of Human Destiny (New York: Little, Brown, 2000). 
Wymans, Gabriel, 'Les Mutineries militaires de 1596 à 1606', Standen en Landen, 39 (1966), 105-21.

Ximénez de Ayllón, Diego, Sonetos a illustres varones este felicísimo y católico ejército y corte (Antwerp: Viuda de Juan Lacio, 1569).

Ydens, Etienne, Histoire dv S. sacrement de miracle (Brussels: Rutger Velpius, 1605).

Zuckerman, Marvin, Sensation Seeking and Risky Behavior (Washington, DC: American Psychologial Association, 2007.

Zurawski, S., 'New sources for Jacques Callot's map of the Siege of Breda', The Art Bulletin, 70 (1988), 621-39.

\section{Online resources}

The most complete overview of source material on the Revolt in the Low Countries can be found at: https://dutchrevolt.leiden.edu/Pages/start.aspx (accessed 14 January 2019).

International Standard Bible Encyclopedia Online: www.internationalstandardbible. com/R/rabshakeh.html (accessed 15 October 2018).

'Besluit vernieuwde kerndoelen WPO' and 'Besluit kerndoelen onderbouw VO', https://wetten.overheid.nl (accessed 12 November 2018).

Cabañas Agrela, J.M., 'Gerónimo de Roda', in Diccionario Biográfico Español (DBE): http://dbe.rah.es/biografias/42941/geronimo-de-roda (accessed 19 June 2018).

Correspondence of William of Orange 1549-1584: http: / / resources.huygens.knaw . nl/wvo (accessed 1 February 2019).

Hortal Muñoz, J.E., 'Charles Philippe de Cröy and Lorrain', in DBE: http: / / dbe.rah. es/biografias / 60855 / charles-philippe-de-croy-y-lorena (accessed 27-2-2019).

Martínez Ruiz, Enrique, 'Sancho Dávila' in DBE: http: / / dbe.rah.es/biografias/5787/ sancho-davila-y-daza (accessed 25 July 2018).

Sánchez Martín, José L., 'Francisco de Valdés' in DBE: http://dbe.rah.es/biogra fias / 4658/francisco-de-valdes (accessed 24 July 2018).

Cabañas Agrela, J.M., 'Alonso de Vargas' in DBE: http://dbe.rah.es/biogra fias/30322/alonso-de-vargas (accessed 23 July 2018).

Cabañas Agrela, J.M., 'Cristóbal de Mondragón' in DBE: http://dbe.rah.es/biogr afias /42982/cristobal-de-mondragon (accessed 7 September 2018).

Versele, Julie, 'Louis del Río' in DBE: http:/ / dbe.rah.es/biografias/65535/louisdel-rio (accessed 12 September 2018). 